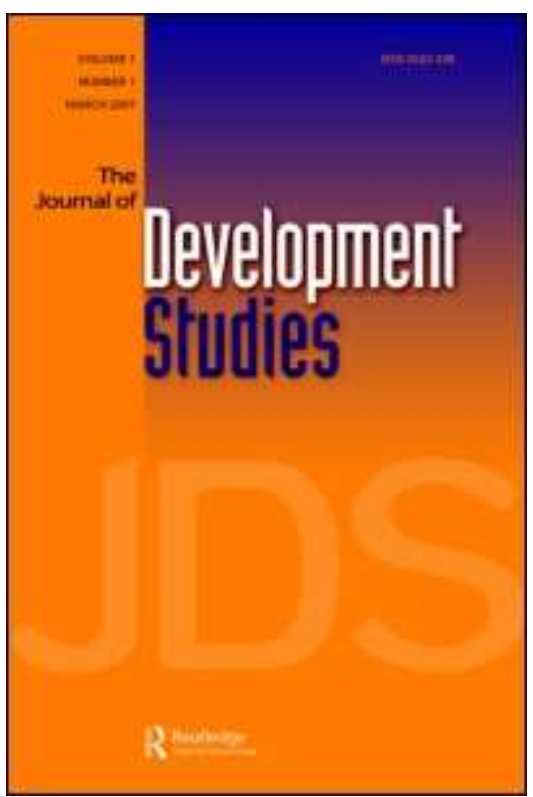

\title{
Child Labour in Indonesian Small Industries
}

\begin{tabular}{|r|l|}
\hline Journal: & Journal of Development Studies \\
\hline Manuscript ID: & FJDS-2010-Jun-0007.R1 \\
\hline Manuscript Type: & Original Manuscripts \\
\hline Keywords: & $\begin{array}{l}\text { Child Labour < Employment and Law, East Asia < Geographical } \\
\text { Area }\end{array}$ \\
\hline \multicolumn{2}{|c}{} \\
\hline
\end{tabular}

\section{SCHOLARONE Manuscripts}




\title{
Child Labour in Indonesian Small Industries
}

September 5, 2010

\begin{abstract}
We analyse the geographic incidence of child labour in small manufacturing firms in Indonesia at the village level. Our unique data set covers virtually all Indonesian villages and urban neighbourhoods; it allows us to distinguish between demand and supply side determinants of child labour. We show by correcting for sample selection that a number of counterintuitive results - child labour being unaffected by credit access and school proximity-are the result of an interplay between supply and demand side determinants. Credit access and school proximity reduce child labour supply, but simultaneously constitute positive location factors for firms thereby increasing the demand for child labourers. To effectively reduce child labour, growth oriented policies, such as enhancing school and credit facilities, should be complemented by policies specifically geared towards increasing school attendance.
\end{abstract}

JEL Classification: J8, I3 


\section{Introduction}

To this day, child labour remains a big developmental problem, not only because it affects child development negatively, but also because it significantly reduces human capital formation and thus growth performance (Duflo, 2001). In order to design appropriate policies to reduce child labour, it is necessary to understand its determinants. This paper contributes to our understanding by analysing demand and supply factors of child labour in Indonesia separately. We employ a unique data set that comprises all Indonesian villages and use the geographic variation in economic conditions to distinguish between determinants of the demand for, and the supply of child labour.

Empirical evidence suggests that child labour is associated with poverty. In cross country analyses GDP per capita turns out as a very powerful determinant of child labour (see Krueger, 1996); and open economies have less child labour due to gains from trade (Edmonds and Pavcnik, 2006). At the micro level, evidence on the effect of income or wealth on child labour is less clear, partly because of the endogeneity of income or expenditures (Bhalotra and Tzannatos, 2003). Edmonds and Pavcnik (2005) show for Vietnam that trade liberalisation has reduced child labour due to positive income effects. Bhalotra (2007) finds that labour supply of boys (not of girls!) in rural Pakistan depends negatively on the own wage-the income effect thus dominates the substitution effect. The analyses of exogenous income transfers also show that child labour declines with income. ${ }^{1}$ Duryea, Lam and Levison (2007) show that Brazilian children are more likely to drop out of school and work instead if the male household head becomes unemployed. These findings suggest the existence of a strong negative income effect on child labour.

Other studies find a positive relationship between wealth and child labour for agricultural households that own land (Bhalotra and Heady, 
2003), which they explain by imperfect land and labour markets. ${ }^{2}$ Basu, Das and Dutta (2009) argue that this relationship has an inverted U shape.

If investment in human capital is profitable, the poor could, in principle, borrow against future earnings and send their children to school. Yet, in many developing countries the poor are thought to have insufficient access to credit, which gives rise to child labour (Baland and Robinson, 2000; Ranjan, 2001). As (insufficient) access to credit is typically not observable, ${ }^{3}$ it has to be inferred from reactions to income shocks. These studies show that in many developing countries child labour increases (decreases) as a reaction to negative (positive) income shocks suggesting that credit constraints are binding. ${ }^{4}$ If credit availability leads to higher capitalisation, returns to child labour may increase and thus schooling may decrease (Wydick, 1999, Guatemala). By contrast, Cameron (2001) and Suryahadi, Priyambada and Sumarto (2005) do not find any significant increase in Indonesian child labour in response to the sharp decline in income during the 1997-1998 crisis. Cost and accessibility of schooling have been shown to be a major determinant for child labour. Programmes that reduce the cost of schooling have proved to raise school attendance and reduce market work (see fn. 1). Accessibility of education proves to be a major determinant of school enrolment in Indonesia (Pradhan, 1998). Extra household work rises with the cost of schooling in rural Pakistan (Hazarika and Bedi, 2003).

These microeconometric studies focus on the determinants of child labour supply, given by household characteristics such as income, wealth, parental education, or family structure. The degree of child labour that we observe, however, is the result of the interplay of demand and supply. For example, Manning (2000) argues that the high unemployment in Indonesia during the 1997-1998 crisis has made it hard for children to find jobs so that child labour did not increase. Thus, negative income shocks may increase the supply of child labour and 
simultaneously decrease the demand for it. We observe only the net effect.

Recently, a number of studies have included demand determinants in their empirical setup. Labour market conditions, influencing both demand for and supply of child labour, have been shown to matter: Duryea and Arends Kuenning (2003) show that adolescent employment in urban Brazil increases with the wage rate. Child labour declines with rising adult employment (Manacorda and Rosati, 2007, Brazil). Wahba (2006) shows that it decreases in Egypt with rising wages for illiterate adult males.

Fafchamps and Wahba (2006) show for Nepal that proximity to urban centres increases school attendance and decreases total child labour, but makes it more likely that children are involved in wage work. Growth of economic activity increases child labour (Kambhampati and Rajan, 2006 and Swaminathan, 1998 for India, Kruger, 2007 for Brazilian coffee production), which points to a dominance of the demand effect over the supply effect.

In this paper we argue that we need to distinguish between supply side and demand side determinants of child labour, not only for analytical reasons, but especially because an effective policy to combat child labour needs to reduce the supply of child labour. The forces driving up the demand for child labour are typically those that increase the demand for adult labour as well and therefore are beneficial to overall development. Yet the distinction between demand and supply factors is far from obvious. While availability of credit is regarded as reducing child labour supply, it may also increase child labour demand as it may lead to higher economic activity and higher demand for (child) labour. The net effect is uncertain a priori. Likewise, economic activity may locate where schools provide an educated labour force and may in its wake increase demand for child labour. Conversely schools may locate where economic activity and thus the return to education is highest. It 
may turn out that school and credit availability are associated with higher child labour; yet this association does not invalidate the remedy of better schools and better access to credit against child labour-it is the result of a dominant demand effect. ${ }^{5}$

In this paper we address these issues. We use a unique data set of all villages and urban neighbourhoods in Indonesia (more than 68 thousand), which includes a rich set of village characteristics, notably child labour incidence in small industries, credit availability, presence of schools, income shocks, a wide range of poverty related variables, local unemployment, geographic indicators, and the economic structure of villages and urban neighbourhoods. The large variation of these village level variables across all of Indonesia allows us to distinguish between the effect of these and other variables on the location decision of small firms - and thereby indirectly on child labour demand - and their effect on the supply of child labour.

We find that child labour in small industries is significantly associated with poverty, negative income shocks, and unemployment. Credit availability has no significant effect on child labour, which is the result of a positive demand side effect and a countervailing supply side effect: credit availability increases the likelihood of small industries locating in a village, and if so, the number of small firms in that village and thereby the demand for child labour while the supply of child labour declines as available credits allow families to react to negative shocks without resorting to child labour income. In other words, the set of villages/urban neighbourhoods that have small firms is a biased sample of all Indonesian villages/neighbourhoods with some of the determinants of child labour also being responsible for the sample selection. If we correct for the sample selection bias, credit availability significantly reduces child labour. This signifies the supply side effect of credit availability. By a similar argument, school availability significantly reduces child labour only after correcting for location 
decisions of small firms. Again, the likelihood of small firms locating in a village increases with school availability.

We proceed as follows. In the next section we lay out the regional and sector incidence of child labour in small industries throughout Indonesia. Section 3 describes the data and sets out the empirical model. Section 4 reports the results, Section 5 concludes.

\section{$2 \quad$ Child labour in Indonesia}

Indonesia has experienced a steady decline in labour force participation rates of children aged 10-14 from 22.1 per cent in 1960 to 7.1 per cent in 2002 and 5.2 per cent in $2007 .{ }^{6}$ This reduction was due to rising living standards, falling family sizes and a structural change that reduced the labour force in agriculture and the cottage and small scale industry, the main sectors in which children worked (Manning, 2000). The reductions in child labour went along with significant improvements in school enrolment. Assisted by a large primary school construction programme (Sekolah Dasar INPRES) that was launched in 1973, primary school enrolment became almost universal already in the mid 1980s.7 The economic crisis in 1997-1998 did not lead to a large secondary school dropout or increase in child labour (Cameron, 2001; Suryahadi et al., 2005), but halted the improvements in child labour for the next two years. Primary enrolment benefited from a social safety net scholarship programme which successfully prevented a decrease in primary enrolment (Sparrow, 2007). Despite improvements in school enrolment and child labour over the last decade, local public primary education is still delivered inefficiently in Indonesia (Lewis and Pattinasarany, 2010).

Child labour and secondary school enrolment are both still closely linked to poverty (Suryahadi et al., 2005). Although Indonesia currently pursues a nine year universal basic education policy (up to the age of 15), around 30 per cent of the children drop out after completing 
primary school (around the age of 12). The dropout rates are considerably higher for the poorest quintile of the population (almost $50 \%$ ) than for the richest quintile (12\%) (Paqueo and Sparrow, 2006). Schooling and work are not mutually exclusive; around half of the working children still go to school, working considerably fewer hours per week than their only working counterparts (Suryahadi et al., 2005).

Indonesian children work predominantly in agriculture, but small scale manufacturing is the second most important sector for child work. At the time of our analysis, in 2002, 65.3 per cent of the working children (10-15 years old) worked in agriculture, 12.2 per cent in manufacturing and 11.3 per cent in trade. ${ }^{8}$ The analysis of child labour in small industries (such as leather, wood, ceramic, and metal processing, weaving and food production) is not only interesting because it is the second most important sector for child labour and has not been the focus of attention in the analysis of child labour. It is particularly interesting because - unlike the ubiquitous agricultural sector - small industries are present only in a subset of villages and urban neighbourhoods. This allows us to disentangle demand and supply side influences on child labour through the endogenous location of these economic activities. To the best of our knowledge, we provide the first study on child labour in Indonesia that identifies explicitly demand and supply side factors leading to the observed market outcome.

\section{Data and Empirical Strategy}

\subsection{Data}

Our data source is the Village Potential Statistics, (Potensi Desa; PODES) of 2003 which was collected in the fall of $2002 .{ }^{9}$ The dataset is compiled by Statistics Indonesia (Badan Pusat Statistik, BPS) in the context of the periodic census and covers 69125 villages and urban neighbourhoods, all villages and urban neighbourhoods in Indonesia. ${ }^{10}$ It consists of a rich set of data at the village level; in particular it reports for each 
village the number of firms in different small scale manufacturing industries (in leather, wood, metal, ceramic, weaving, food, and other industries) and whether children are employed in these sectors. In addition, the data set contains a rich set of village level variables on the availability of different kinds of credit, presence of or distance to schools and markets, various other infrastructure variables, population, unemployment rate, geographic and poverty variables, and proxies for social capital.

In one dimension our data set is much more comprehensive than those of existing microeconometric studies which are typically confined to small geographical areas: we have data on virtually every village in Indonesia. ${ }^{11}$ Because Indonesia is so vast and so heterogeneous in structure, poverty incidence, and geography, this allows us to address the roles that these variables play in determining child labour incidence. This great geographic coverage comes at the cost of not being able to assess the number of child labourers in any village, but only sectoral and geographic child labour incidence. Our main dependent variable is an indicator variable that takes one if village heads/neighbourhood heads report that children are working in any of the small scale manufacturing industries in the village. ${ }^{12}$ Thus, we cannot directly assess the intensity of child labour, and we do not capture child labour in other sectors, notably not in agriculture. Nonetheless, our geographic child labour prevalence variable is reasonably correlated with information on the intensity of child labour based on Susenas, the Indonesian national household survey. The province level correlation between average labour force participation of children (aged 10 to 14) in manufacturing and our measure of child labour prevalence amounts to 0.66 , the correlation between overall workforce participation of children and our child labour measure amounts to 0.52 (see Figure 1). ${ }^{13}$ The sectoral and regional patterns of geographic incidence of child labour in manufacturing are given in Table $1 .{ }^{14}$ Child labour incidence is 
strongest in the food, ceramic and wood sectors, which have the highest prevalence in villages. Conditional incidence is highest in the food and ceramic sectors-a quarter of villages that have small firms in that sector have children working there.

Child labour incidence-measured as percentage of villages in which children work in small industries-is highest in the central islands, Java (20\%) and Bali/Nusa Tenggara (20\%), and lowest on the periphery, in Irian Jaya (3\%) and Maluku (7\%). Java and Bali/NTG have the highest values for firm presence and the highest number of firms per village (conditional mean) while Iran Jaya has the lowest presence and density of small firms, suggesting that a high level of economic activity may be associated with higher levels of child labour demand. The very different picture for child labour incidence conditioned on the existence of small firms is in line with this suggestion: It is highest in Kalimantan (39\%) and Iran Jaya (33\%) and lowest in Maluku (23\%) and Java (27\%). The demand of child labour is likely to be lower in the periphery as economic activity is lower, even though the supply is probably higher. ${ }^{15}$ In other words, child labour incidence in small scale manufacturing in a location is increasing in firm presence and the number of firms in that location. ${ }^{16}$ Therefore, factors determining firm location matter for regional child labour incidence.

\subsection{Empirical Strategy}

\subsubsection{Observable Market Outcome}

Observable child labour incidence is an equilibrium outcome of the interplay of the demand for and the supply of child labour. The supply of child workers needs to find its demand if child labour is to be observed; an exclusive focus on supply side determinants in empirical analyses thus implicitly assumes that the demand side will accommodate any change in the supply of child labourers. This is a restrictive assumption; in our case it is too restrictive as we are focusing on child labour in 
small industries and only around half of all villages have small industries at all (see Table 1).

As we have seen in Table 1, the probability of child labour in a given location rises with the number of small firms; this suggests that the level of economic activity is the driving force behind the demand for child labour. Thus the demand for child labour is affected by all variables that affect the location decisions of firms (and their subsequent growth). Among these variables are the proximity to market, the availability of qualified labour and credit, the quality of infrastructure and the geographic location, which influence accessibility and thus transport costs. Lastly, local purchasing power should matter as well.

Poverty is a strong determinant of child labour supply as it indicates the need to rely on children's' income for household survival (compare literature in section 1). Thus, poverty related variables should turn out significantly. The existence of negative income shocks (for example through diseases or unemployment) and the inability to cushion these effects through borrowing (insufficient access to credit) should increase child labour supply. Lastly, opportunity costs of child labour, especially the proximity and accessibility of schools, influence the decision to send children to work (see section 1).

A particular problem arises in our context because some of the variables may capture demand and supply side effects at the same time. For instance, access to credit may reduce child labour supply, but it is also a location factor for (small) firms. Schools increase the quality of the labour force and thus capture a location factor, but they also increase the opportunity costs of child labour. Before we address this issue and a possible sample selection bias created by endogenous firm location, we will discuss supply and demand factors for child labour at the village level. 


\subsubsection{The Supply Factors}

In accordance with the literature, we expect that the supply of child labour depends positively on the degree of poverty in a village. As our data set does not include information on income we use the following proxies:17 The variable bad housing measures the share of families that live in non-permanent houses. Because fertility is closely related to poverty, we include average family size in the village. Lastly, the share of families with electricity is inversely related to poverty.

Income shocks may create the need to smooth consumption by sending children to work. We measure negative shocks by the number of deaths caused by epidemics that occurred in the previous year as a percentage share of total population. To the extent that epidemics are not randomly located across Indonesia, the epidemic death rate might also be proxying for village poverty. The level of unemployment may increase child labour supply. If the main income earner becomes unemployed, labour supply by children may increase in order to (partly) compensate the loss in income.

Credit allows poor households to send their children to school instead of having to rely on their income to support the family. Especially if families experience a negative transitory income shock, they may borrow instead of using child labour as a consumption smoothing device. Villages where households have access to credit may thus be less likely to experience child labour, other things being equal. Yet, even if formal credit programmes are available at the village level, the poorest households will not necessarily have access to credit facilities because of a lack of collateral. Even if people have access to credit, credit facilities may be insufficient or people may opt to compensate the loss of income by a combination of credit and child labour.

The ability of the households to cope with income shocks might also depend on informal credit networks and the strength of the local social 
safety nets. Rotating saving and credit associations (arisans) may help cushion negative shocks. ${ }^{18}$ Collective labour arrangements (gotong royong) include various labour practices, like the mutual help arrangements, but also collective (unpaid) village labour which is required for the village development programs. ${ }^{19}$ Both institutions may indicate a higher level of social capital and thus less need to resort to child labour in times of crises.

The decision to send children to work rather than to school depends also on the opportunity costs of work. These are higher if schools are nearby and thus easy to reach. Obviously, children could work and go to school, but the likelihood that children work can be expected to be lower if they go to school (Bhalotra and Tzannatos, 2003). We thus hypothesise that the likelihood of child labour goes down with the number of 'relevant' schools in the village. We include the presence of primary schools and separately the presence of secondary schools in the regressions.

Lastly, the probability of child labour occurrence should increase with overall population, as there are more potential child labourers. To allow for nonlinear influence we included a third order polynomial of population. 


\subsubsection{The Demand Factors}

The demand for child labour depends on the overall demand for labour, which is a function of economic activity, and on the availability of the alternative to child labour-adult labour. The latter is proxied by the level of unemployment. Therefore, the higher the unemployment rate, the lower the demand for child labour, other things being equal. Yet, as noted in the previous section, unemployment raises the supply at the same time-we observe only the impact on the market outcome.

The level of economic activity in the sector of small manufacturing industries is proxied by the number of small firms. We include a bivariate third order polynomial of the number of small firms and population size in order to allow for a nonlinear influence. Because the number of firms alone does not completely capture the level of economic activity (as firms can have different activity levels) we include the location factors for these small firms in the regression as well, assuming that the factors that make firms locate in a certain village/neighbourhood make them flourish as well. Small firms in these sectors are located only in 51.3 per cent of all villages (Table 1). In order to identify the relevant location factors we present results from a Tobit model on the number of small firms in a village/urban neighbourhood. ${ }^{20}$ Results are reported in Table 3. They guide our choice of variables for the demand side of child labour.

Input availability is a major location factor. We include the availability of skilled labour as proxied by the presence of any primary as well as secondary schools. Both turn out significant in the regressions on the location of small firms: primary and secondary school presence exert significant positive influences on the probability of firm presence and, if present, on the number of firms. Both variables should at the same time reduce the supply of child labour (see section 3.2.2). 
Availability of credit, particularly when it is specifically designed for small businesses, is a major determinant for the decision to locate in a certain village. Access to credit also enhances the level of economic activity and thus the demand for child labour, other things being equal. ${ }^{21}$ We differentiate between a broad measure of credit access, that includes all forms of formal credits, and small business credit that caters specifically to the firms under consideration. PODES collects data on various forms of subsidised and unsubsidised formal small scale credits available within a village. Most importantly for our purposes, 31.9 per cent of the villages report the presence of an unsubsidised investment credit programme for small businesses (KUK, Kredit Usaha Kecil). This credit programme has been introduced in 1990 in order to provide loans of limited size to small businesses and is targeted at small firms and not households (Lapenu, 1999). PODES records information on other loan programmes such as farm credits or housing credits and on whether any other form of formal credit is available. ${ }^{22}$ Based on this, we code two binary variables: Credit access takes one if there is any form of formal credit available in a village, while small business credit takes one if the village has access to the firms' investment credits.

The broad measure of credit access is a demand factor and a supply factor at the same time as it tends to increase economic activity and opens up the opportunity to send children to school without an unsustainable drop in consumption. In contrast, the small business credit works only on the supply side as it is available only for business purposes.

Both measures for social capital, the presence of collective labour arrangements (gotong royong) and of rotating saving and credit associations (arisans) are positive location factors, with gotong royong having a larger influence than arisans.

Market size and proximity to the relevant market are major determinants for firm location and firm success. We measure market 
proximity by the presence of a village market as well as the distance to the nearest permanent market. Purchasing power of the local population is proxied by population size and the variables indicating poverty: the share of population with (non-permanent) bad housing, average family size, and share of families with electricity. The latter variable also indicates the quality of infrastructure and thus should exert a positive influence beyond the income and wealth effects. These variables all are demand factors as well and exert an influence opposite to their effects on child labour supply (see above).

Better access to infrastructure and lower transport costs are reflected by the geographic variables, indicating a coastal location or a location in lower altitudes. The variable indicating urban neighbourhoods or villages captures in addition to closer proximity to markets a better infrastructure as well as a higher local purchasing power. They are all expected to raise economic activity. To control for unobservable characteristics of various parts of the archipelago such as differences in culture, institutions, and mentality we include province or district fixed effects.

\subsubsection{Econometric Specification}

As we observe only the existence, but not the extent of child labour in a village, we estimate the probability of child labour incidence $L$ in village $j$, region $k$ by probit models of the form

$$
\operatorname{Pr}\left(L_{j k}=1\right)=\operatorname{Pr}\left(x_{j k} \beta+\lambda_{k}+\varepsilon_{j k}>0\right)
$$

where $x_{j k}$ is a vector of controls specified above, including a bivariate third order polynomial in the number of firms and population size, and a further set of location and other supply factors, and $\lambda_{k}$ stand for province or district fixed effects. By including regional fixed effects, we focus on the role of within province/within district variation in economic conditions for child labour. As economic and cultural backgrounds vary vastly between Indonesian regions, regional fixed 
effects can gauge large parts of this unexplained heterogeneity. Because child labour in small manufacturing firms can occur only in locations that have such small firms, we run the probit model only on the subset of villages with small firms.

As we can observe child labour only in those villages where small manufacturing firms operate, probit models lead to biased estimates on those variables that affect not only child labour but also industrial location. As we have seen, this applies to a number of variables. For example, we expect that the opportunity costs of child labour increase when a primary school is present in the village, that is, school availability reduces child labour incidence. At the same time, if small firms locate preferably in villages with a population with higher basic skills, the effect of school availability on child labour will be biased downwards and may even change its sign. In other words, for any given number of firms, school availability reduces child labour; but since the number of firms depends positively on school availability and more firms increase the likelihood of child labour we have two countervailing effects of school availability on local child labour incidence-the opportunity cost effect and the location effect. The former refers to the supply side of, the latter to the demand side for child labour. In a simple probit estimation we explain only the net effect for the restricted sample of villages that have small firms. It may have either sign. If the location were random, we would still observe the effect of school availability on the supply of child labour. A possible demand side effect of increased schooling would be limited to overall higher economic activity, if at all, but no longer lead to a sample selection bias with firms locating in villages with more schools. ${ }^{23}$ A similar argument can be made for example for credit availability.

We address the sample selection problem by estimating a probit model with sample selection correction (Wooldridge, 2002, p. 570), where at the selection stage we condition on the binary variable $S_{j k}$, which 
indicates whether small firms operate in village $j$ in region $k$. Firm location is assumed to depend on the same vector of locational factors $x_{j k}$ as before: ${ }^{24}$

$$
\operatorname{Pr}\left(S_{j k}\right)=\operatorname{Pr}\left(x_{j k} \gamma+z_{j k} \varphi+\lambda_{k}+v_{j k}>0\right)
$$

The model is estimated by maximum likelihood under the assumption of joint normality of $\varepsilon_{j k}$ and $v_{j k}$. At the outcome stage we explain the existence of child labour by the same regression as in (1).

We identify the model with sample selection correction by including the availability of a credit scheme targeted to small businesses as an instrument $z_{j k}$. After controlling for overall credit access, the availability of specific business credits that are targeted only at small businesses for business purposes should not capture any supply effect of child labour (see section 3.2.3). Households do not have direct access to it and thus cannot use it to finance consumption that they would need to forgo if they decided to send their children to school. At the same time, the availability of specific small business credits is an important location factor for small businesses (and increases their number, see Table 3), and thereby raises the demand for child labour by increasing firm activity. ${ }^{25}$ Thus, after controlling for overall credit availability, small business credits affect child labour only through their effects on the presence of small firms, but not through any channel independent of the location of firms.

\section{$4 \quad$ Results}

We report two sets of results in Table 4. Columns 1 and 2 contain the results from the probit model on child labour occurring in a village/urban neighbourhood conditional on small manufacturing firms being present in that location. ${ }^{26}$ The exclusion of the locations without small firms makes sense, because PODES measures only child labour in that sector. Including locations that cannot have the type of child labour 
that we measure would lead to biased estimates. The conditional probit model of columns 1 and 2 thus estimates the determinants of child labour incidence for the set of locations that have small firms.

However, this sample is not representative for all of Indonesia, because the villages with small firms differ systematically from the 'average' village; they are more attractive locations for small firms (see Table 3). Determinants of child labour will have a different impact in a random sample than in this biased sample. We thus report also the results of a probit model with sample selection. The endogenous variable at the selection stage is a binary variable that is one if small firms are present in a location (columns 5 and 6); the endogenous variable at the outcome stage is a binary variable for the occurrence of child labour in that location (columns 3 and 4).

We run both models with fixed effects at the province level (odd numbered columns) and at the district level (even numbered columns) to control for unobserved heterogeneity. While district level fixed effects allow to capture unobserved heterogeneity at a more disaggregated level they come at the cost of reduced observationsdistricts that have only villages/neighbourhoods either with or without child labour drop out in both models; in the model with sample selection districts that have only villages with or without small firms are dropped in addition. Overall, results are similar. Table 4 reports marginal effects evaluated at the sample mean.

In the conditional probit model, access to credit has no significant effect on child labour. This result is at odds with conventional wisdom, but it masks two countervailing effects: Credit access increases significantly the likelihood of firms being present in a location by around 14 percentage points. This shows a significant demand side effect of credit access. At the outcome stage credit access reduces child labour. This effect is significant in both models-given that there are firms, the availability of credit reduces the probability of child labour occurrence 
by 5 to 8 percentage points. This portrays the typical supply side effect of credit availability on child labour. The effect of credit programmes specifically targeted at small businesses increases the probability of child labour in the conditional probit model significantly by 2 percentage points; this effect can be traced back to a significantly higher probability of small firms locating in that village. As argued in the previous section, we use small business credit to identify the probit model with sample selection as the variable captures the additional effect of specific credit facilities for small businesses (beyond the broad measure of credit), which attract small businesses but are not available to households to finance consumption.

Our social capital variables, indicating the presence of rotating saving and credit associations (arisans) and collective labour (gotong royong) arrangements, are not associated with lower child labour in the conditional probit model; child labour is even higher in villages that have artisans (in the model with district fixed effects). Yet again, both social capital variables are associated with a higher likelihood of firms locating in that village, and with a higher activity level (see also Table 3). When controlling for this effect, collective labour arrangements make child labour significantly less likely (by about 7 percentage points), while the positive correlation with saving groups vanishes. Thus, social capital plays an important role for child labour, with distinctively different demand and supply side effects.

The conditional probit model suggests that primary school presence increases child labour incidence significantly, while secondary school presence has no impact. Again, this runs counter the notion that lower costs of schooling (more accessible schools) reduce child labour. The results that control for sample selection show that the presence of primary and secondary schools are significantly associated with a higher probability of firms locating in that village/neighbourhood and thus indicate favourable location factors, especially a labour force with 
better skills. At the outcome stage, however, child labour incidence decreases with secondary school presence while primary school presence has no statistically significant impact. This set of results shows that close-by schools attract firms and would be child labourers alike, but that this relationship is stronger for firms than for children.

Unemployment and epidemic death rate do not influence location decisions, probably due to the transitory nature of the underlying shocks. Therefore, both factors have the same effect in the conditional probit model and at the outcome stage of the model with sample selection: They significantly increase child labour. For epidemics this was to be expected; in case of unemployment the increased child labour supply effect seems to outweigh the effect of a larger idle adult workforce, which could be hired instead of children. Since world-wide most child labourers work within their households (Edmonds 2008), our result implies that in situations of higher unemployment-and thus larger need-families do not resort to outside labour, but to their own children for work. One reason may be that they are cash constrained and cannot afford outside help, even though it is more readily available; the second reason may be that labour markets are imperfect in that hired workers may be tempted to shirking while family members are not. This is in line with the empirical evidence that land owners, though richer, are more likely to send their children to work (see Bhalotra and Heady 2003).

Bad housing increases child labour in the conditional probit model with district controls and is insignificant in the model with province controls. Family size, the other proxy for poverty, does not turn out significant in both specifications of the conditional probit model. Again, these results veil the underlying forces: Poverty variables are associated with a lower likelihood of firms being present, they serve as a locational disincentive (as the local purchasing power is lower); at the outcome stage, a larger share of households with bad housing significantly increases the 
probability of child labour. In other words, the conditional probit model underestimates the supply side effect of bad housing, or more generally of poverty, due to a countervailing demand side effect. The same applies for family size, yet the relationship is not as close.

The presence of a village market as well as closer distance to the next permanent market and being an urban or a coastal neighbourhood/ village make the location more attractive for small industries and thus increase the probability of small firms residing in that location. Yet they have no significant effect on child labour at the outcome stage and are insignificant in the conditional probit model as well. Locations in lower altitudes are more attractive for firms, but have a lower probability of child labour at the outcome stage; in the conditional probit the variable is insignificant. The share of families with electricity increases child labour incidence in the conditional probit model; in part due to a positive effect on the probability of firms locating in that village as the infrastructure is better and due to a higher probability of child labour at the outcome stage (only in the model with district controls). A potential explanation for this latter effect could be that infrastructure quality (electrification) increases the intensity of firm activity (beyond its location and numbers) to an extent that the demand effect on child labour dominates the supply side effect of better off households.

We control for population size by including a third order polynomial, which turns out significant in all regressions (not reported): with rising population the probability of child labour increases significantly (in a nonlinear way). This captures a supply side effect: As the number of potential child labourers increases, it becomes more likely that child labour occurs.

The polynomial in the number of firms in the village is also highly significant-child labour becomes more likely the larger the number of firms in the village. ${ }^{27}$ This captures an important demand side effect: We corrected for the sample selection bias in our probit model that arose 
from analysing only villages/neighbourhoods that had at least one small manufacturing firm. The outcome stage thus includes variables that measure supply and demand factors given that there is a least one firm. An obvious control for the demand level is the number of firms in the village/neighbourhood. Thus the other variables at the outcome stage include demand side effects only insofar as they have not been controlled for by the number of firms, but they capture the entire supply side effect.

\section{Conclusion}

We have analysed the geographic incidence of child labour in small manufacturing firms in Indonesia with the help of a unique data set that covers virtually all Indonesian villages and urban neighbourhoods. Previous empirical studies have used either large household data sets or cross-country data sets. The geographic variation in our data has allowed us to distinguish between demand and supply side determinants of child labour in a way that would not be possible in other types of data sets.

We have shown that many determinants of child labour affect the demand for and the supply of child labour simultaneously, but often in opposite directions. While the demand for child labour is positively correlated with the level of economic activity, the supply of child labour is rooted in poverty, negative income shocks, the absence of accessible schools and credit facilities, among other things. If, for instance, credit facilities are improved, the level of economic activity increases, which tends to raise the demand for child labour; at the same time better access to credit reduces the supply of child labour. In our sample the overall effect of credit availability turns out insignificant; such a result however blurs the underlying relationships. Similarly, primary school presence increases child labour, however, only through its positive effect on the level of economic activity. Secondary schools are also 
significantly associated with higher economic activity levels, which tend to increase child labour demand, but their presence reduces child labour supply significantly rendering the overall effect insignificant.

Interestingly, social capital has an important impact on child labour. We measure social capital by the existence of informal rotating saving and credit associations (arisans) and by collective labour arrangements (gotong royong) designed for mutual help or community development. Arisans are associated with higher economic activity and thus raise child labour. Collective labour arrangements increase economic activity as well, but reduce child labour supply at the same time, so that their overall effect is insignificant.

Poverty related variables such as the share of people living in nonpermanent houses or average family size are associated with a lower level of economic activity. Thus poverty reduces the demand for child labour and increases the supply of child labourers at the same time. An aggregated view on the impact of poverty on child labour would thus underestimate the extent to which poverty makes families ready to send their children to work. As noted earlier, a similar line of reasoning applies to school accessibility.

A disaggregated perspective, such as the one we have taken enhances our understanding of child labour incidence; more importantly it has significant policy implications. Most demand factors for child labour are linked to the level of economic activity. As an increase in economic activity is desirable for many reasons, notably poverty alleviation, these variables do not provide an entry point in the fight against child labour. Yet, our finding that unemployment increases child labour incidence does provide such an entry point on the demand side. Unemployment increases the supply of child labour (as household income is reduced by unemployment); at the same time it increases the pool of available adult labourers, who are a substitute to child labourers. Thus making adult labourers more attractive to employers compared to child labourers 
reduces child labour incidence. Most child labourers work in their parents' businesses; this implies that in times of unemployment families send increasingly their children to work instead of hiring adult labour outside the family despite the high returns to educational investment. Thus our finding points either to existing cash constraints of families, who cannot afford to pay outside help, or to labour market imperfections, notably shirking, that make outside help less attractive (see Sect. 5). Improved credit facilities and in particular collective labour arrangements that help to build up social trust may be instrumental in reducing child labour.

On the supply side our results corroborate earlier findings-enhanced credit and school accessibility and poverty reducing policies decrease child labour supply. As the supply side provides better entry points for policy interventions, old prescriptions still apply. Yet we cannot be certain that these policies will lead to a reduction of child labour in the short run as they increase economic activity. This may be frustrating, yet it does not invalidate the general approach. In the worst case, we may see an inverted $U$ shape relationship between child labour incidence and economic development. These transitory increases in child labour can be avoided, however, if growth enhancing policies are complemented by policies specifically designed to reduce child labour supply 'such as cash transfers conditional on school attendance or free school meals or school transport. They can also be prevented if increased economic activity translates into higher income of the poor families who would send their children to work in the absence of income gains. ${ }^{28}$ Thus growth promoting policies need to ensure that growth includes the poor. 


\section{References}

Baland, J.-M. and Robinson, J. A. (2000) Is child labor inefficient? Journal of Political Economy, 108(4), pp. 663-679.

Basu, K., Das, S. and Dutta, B. (2009) Child labor and household wealth: theory and empirical evidence of an inverted-U. Journal of Development Economics, 91(1), pp. 8-14.

Beegle, K., Dehejia, R. H. and Gatti, R. (2006) Child labor and agricultural shocks. Journal of Development Economics, 81(1), pp. 80-96.

Bhalotra, S. (2007) Is child work necessary? Oxford Bulletin of Economics and Statistics, 69(1), pp. 29-55.

Bhalotra, S. and Heady, C. (2003) Child farm labor: the wealth paradox. World Bank Economic Review, 17(2), pp. 197-227.

Bhalotra, S. and Tzannatos, Z. (2003) Child labor: what have we learnt? Social Protection Discussion Paper Series, No. 317, World Bank, Washington D.C.

Bourguignon, F., Ferreira, F. and Leite, P. G. (2003) Conditional cash transfers, schooling, and child labor: micro-simulating Brazil's Bolsa Escola Program. World Bank Economic Review, 17(2), pp. 229-254.

Bowen, John R. (1986) On the political construction of tradition: Gotong Royong in Indonesia. Journal of Asian Studies, 45(3), pp. 545-561.

Cameron, L. A. (2001) The impact of the Indonesian financial crisis on children: an analysis using the 100 villages survey. Bulletin of Indonesian Economic Studies, 37(1), pp. 43-64.

Dehejia, R. H. and Gatti, R. (2005) Child labor: the role of financial development and income variability across countries. Economic Development and Cultural Change, 53(4), pp. 913-932.

Duflo, E. (2001) Schooling and labor market consequences of school construction in Indonesia: evidence from an unusual policy experiment. American Economic Review, 91(4), pp. 795-813.

Duryea, S. and Arends Kuenning, M. (2003) School attendance, child labor and local labor market fluctuations in urban Brazil. World Development, 31(7), pp. 1165-1178.

Duryea, S., Lam, D. and Levison, D. (2007) Effects of economic shocks on children's employment and schooling in Brazil. Journal of Development Economics, 84(1), pp. 188214.

Eberhard, A. and Schulze, G. (2010) Rotating savings and credit associations in Indonesia. Unpublished manuscript, University of Freiburg.

Edmonds, E. V. (2008) Child Labor, in: T. Schultz, J. Strauss: Handbook of Development Economics, Vol. 4, (Amsterdam: North Holland, Elsevier), pp. 3607-3709.

Edmonds, E. V. (2005) Does child labor decline with improving economic status? Journal of Human Resources, 40(1), pp. 77-99.

Edmonds, E. V. and Pavcnik, N. (2005) The effect of trade liberalization on child labor. Journal of International Economics, 65(2), pp. 401-419.

Edmonds, E. V. and Pavcnik, N. (2006) International trade and child labor: crosscountry evidence. Journal of International Economics, 68(1), pp. 115-140. 
Fafchamps, M. and Wahba, J. (2006) Child labor, urban proximity, and household composition. Journal of Development Economics, 79(2), pp. 374-397.

Guarcello, L., Mealli, F. and Rosati, F. C. (2009) Household vulnerability and child labor: the effect of shocks, credit rationing, and insurance. Journal of Population Economics, 23(1), pp. 169-198.

Hazarika, G. and Bedi, A. (2003) Schooling costs and child work in rural Pakistan. Journal of Development Studies, 39(5), pp. 29-64.

Jacoby, H. G. and Skoufias, E. (1997) Risk, financial markets, and human capital in a developing country. Review of Economic Studies, 64(3), pp. 311-335.

Kambhampati, U. S. and Rajan, R. (2006) Economic growth: a Panacea for child labor? World Development, 34(3), pp. 426-445.

Kis-Katos, K. (2007) Does globalization reduce child labor? Journal of International Trade and Economic Development, 19(1), pp. 71-92.

Krueger, A. B. (1996) Observations on international labor standards and trade, NBER Working Papers, No. 5632, National Bureau of Economic Research, Cambridge, Mass.

Kruger, D. I. (2007) Coffee production effects on child labor and schooling in rural Brazil. Journal of Development Economics, 82(2), pp. 448-463.

Lapenu, C. (1999) Indonesia's rural financial system: the role of the state and financial institutions. World Bank Microfinance Case Studies, March 1999, World Bank, Washington D.C.

Lewis, B. and Pattinasarany, D. (2010) The cost of primary education in Indonesia: do schools need more money?, Education Economics, forthcoming, DOI: 10.1080/09645290903358397

Manacorda, M. and Rosati, F. C. (2007) Local labor demand and child labor, UCW Working Paper 34, Understanding Children's Work (UCW Project).

Manning, C. (2000) The economic crisis and child labor in Indonesia, ILO/IPEC Working Paper, International Labour Office, Geneva.

Paqueo, V. and Sparrow, R. (2006) Free basic education in Indonesia: policy scenarios and implications for school enrolment, Unpublished Manuscript, World Bank, Jakarta.

Parikh, A. and Sadoulet, E. (2005) The effect of parents' occupation in child labor and school attendance in Brazil. CUDARE Working Papers, No. 1000, Department of Agricultural and Resource Economics, UCB, University of California, Berkeley.

Pradhan, M. (1998) Enrolment and delayed enrolment of secondary school age children in Indonesia. Oxford Bulletin of Economics and Statistics, 60(4), p p. 413-430.

Ranjan, P. (2001) Credit constraints and the phenomenon of child labor. Journal of Development Economics, 64(1), pp. 81-102.

Ravallion, M. and Wodon, Q. (2000) Does child labour displace schooling? Evidence on behavioural responses to an enrollment subsidy, Economic Journal 110(mrz), pp. C158-175.

Schultz, T. P. (2004) School subsidies for the poor: evaluating the Mexican Progresa poverty program. Journal of Development Economics, 74(1), pp. 199-250.

Sparrow, R. (2007) Protecting education for the poor in times of crisis: a n evaluation of a scholarship programme in Indonesia. Oxford Bulletin of Economics and Statistics, 69(1), pp. $99-122$. 
1

2

3

4

5

6

7

8

9

10

11

12

13

14

Suryahadi, A., Priyambada, A. and Sumarto, S. (2005) Poverty, school and work: children during the economic crisis in Indonesia. Development and Change, 36(2), pp. 351-373.

Swaminathan, M. (1998) Economic growth and the persistence of child labor: evidence from an Indian city. World Development, 26(8), pp. 1513-1528.

Thomas, D., Beegle, K., Frankenberg, E., Sikoki, B., Strauss, J. and Teruel, G. (2004) Education in a crisis. Journal of Development Economics, 74(1), pp. 53-85.

Wahba, J. (2006) The influence of market wages and parental history on child labour and schooling in Egypt. Journal of Population Economics, 19(4), pp. 823-852.

Wooldridge, J. M. (2002) Econometric Analysis of Cross Section and Panel Data, The MIT Press, Cambridge, Mass.

World Bank: 2004, World Development Indicators, CD-ROM, (World Bank: Washington DC).

Wydick, B. (1999) The effect of microenterprise lending on child schooling in Guatemala. Economic Development and Cultural Change, 47(4), pp. 853-869. 
1 The Food for Education programme in Bangladesh (Ravallion and Wodon, 2000), the Mexican Progresa (Schultz, 2004), or Brazil's Bolsa Escola programme (Bourguignon, Ferreira and Leite, 2003) are examples. If the programme reduces the cost of schooling at the same time, it provides an additional incentive to substitute school attendance for labour (even though both occupations are not mutually exclusive).

2 Parikh and Sadoulet (2005) make a similar argument for family businesses in Brazil.

${ }^{3}$ The only exception is Guarcello, Mealli and Rosati (2009) who measure credit restrictions directly through a survey recording credit history and find that credit constrained families in Guatemala are less likely to send their children to school and more likely to increase child labour in response to negative income shocks.

${ }^{4}$ Dehejia and Gatti (2005) show that income volatility affects child labour more in countries with low financial development. School attendance in rural India declines in response to unanticipated seasonal fluctuations in household income (Jacoby and Skoufias, 1997). Tanzanian farmers react to transitory income shocks with increased child labour, but this increase is lower for farmers with durable assets, who can be assumed to have better access to credit due to their collateral (Beegle, Dehejia and Gatti, 2006). Edmonds (2005) shows that the introduction of a large pension scheme for black South Africans reduced work of those children living with recipients of the pension, but not of those living with future pensioners, again pointing to existing credit constraints.

${ }^{5}$ Even if credit and school availability are negatively associated with child labour, their true effect may be underestimated due to the endogeneity of economic activity.

6 Source: World Bank (2004) and Susenas 2002 and 2007. From 1960 to 2002, worldwide labour force participation rates of children declined from 24.9 per cent to 10.6 per cent (World Bank 2004).

${ }^{7}$ From 1974 to 1978 more than 61,000 primary schools were built. This has led to large increases in primary school enrolment rates and had significant long term labour market impacts (cf. Duflo 2001, 2004).

${ }^{8}$ These figures are based on data from Susenas 2002.

${ }^{9}$ We use the 2003 round of PODES as this was the only year when the questionnaire included both information on small industries and on child labour occurring in these industries.

| ${ }^{11}$ The Indonesian '100 village survey' that has been used to analyse the effect of the 1998 crisis on child labour and schooling covers only 10 out of 292 districts at that time and oversamples poor and rural districts (see Cameron, 2001; Suryahadi et al., 2005). Even the rich longitudinal Indonesian Family Life Survey (IFLS) dataset represents only 13 out of 30 Indonesian provinces (Thomas et al., 2004). Studies on child labour in other countries typically cover only a geographic portion of the country.

12 The PODES questionnaire asks for the existence of small scale industries in the following sectors: (1) leather handicraft, (2) wooden handicraft, (3) metal/precious metal handicraft, (4) weaving/pottery/ceramics, (5) embroidery, (6) food, (7) others and asks directly whether children are employed in the respective sector (yes/no). Thus our dichotomous variable refers to the prevalence of market related child labour in these sectors (and not in other sectors), whether paid or unpaid. The information on child labour incidence in these sectors and on whether and if so how many firms exist in these sectors in a given village/neighbourhood allows us to disentangle supply side and demand side effects on child labour.

${ }^{13}$ The corresponding district level correlations amount to 0.383 and 0.077. Data refer to 2002 . 
${ }^{14}$ See Table A1 in the online appendix for a more detailed picture on child labour incidence and firm density by industry for the seven large island groups.

15 Note that we condition on the existence of small firms in the village; thus differences in the conditional child labour incidence are partly determined by the firm density. Yet other factors are at work too. For instance Sulawesi and Kalimantan have comparable firm densities, but markedly different conditional child labour incidence rates. Firm density may be an incomplete measure for economic activity; yet supply factors may be different as well.

${ }^{16}$ For a more formal exposition see Table $\mathrm{A} 2$ in the online appendix and the related explanations.

${ }^{17}$ Definitions and descriptive statistics of all variables used are given in Table 2.

18 This presupposes however that shocks are not highly correlated across members of the arisans and that individuals exposed to a shock can secure the pot; the arisans have to be bidding arisans rather than arisans with a predetermined or random order. Yet the existence of arisans may indicate a larger social cohesion and better informal help mechanisms even if the present arisan cannot be used to smoothen negative shocks. For an empirical analysis of rotating saving and credit associations in Indonesia see Eberhard and Schulze (2010).

${ }^{19}$ Mutual help arrangements (gotong royong) are originating in Javanese cultural values and are almost universal in central districts, while relatively less prevalent on outer islands (like Maluku or Papua).

20 The results from this tobit specification are comparable to results from a Heckman selection model on firm numbers (see Table A3 in the online appendix).

21 One could argue that causality runs both ways as credit facilities are more likely to be located where demand for credit is higher. This would not invalidate our analysis as we argue that availability of credit is associated with higher economic activity (regardless of the direction of causality) and that higher economic activity tends to increase the demand for child labour.

${ }^{22}$ In more than half $(53.8 \%)$ of the villages households have access to some form of formal credit; in 21.9 per cent of villages there is access to microcredit, but no access to the business credit programme (KUK).

${ }^{23}$ Strictly speaking, the demand effect at the village level consists of a sample selection effectvillages with schools tend to have a larger share of small firms-and a level effect: schools lead to overall higher economic activity. We can control for the former, the latter effect will be observed jointly with the supply side effect.

${ }^{24}$ The only difference between the two sets of controls is that in eqn. (2) $x_{j k}$ includes only a third order polynomial in population size (instead of the bivariate third order polynomial in population size and firm numbers of eqn. (1)).

${ }^{25}$ When estimating the sample selection model without exclusion restrictions (identified by the functional form only), small business credits turn out to be completely insignificant in the regressions explaining child labour (results are available on request). However, this not constitutes a formal test of instrument validity.

${ }^{26}$ We have additionally controlled for economic structure, additional infrastructure variables (on roads and ports) and shocks at the village level (floods, landslides, earthquakes). As this has not changed our basic results we have opted for a more parsimonious specification.

${ }^{27}$ We also find significant interaction effects between population size and firm numbers. 
${ }^{28}$ See also Kis-Katos 2007 for income effects of the poor on child labour. 


\section{A Tables}

Table 1: Child labour incidence in small scale industries (village level)

\begin{tabular}{|c|c|c|c|c|}
\hline \multirow[b]{3}{*}{ By industry: } & & \multicolumn{2}{|c|}{ Small firms } \\
\hline & \multicolumn{2}{|c|}{$\begin{array}{l}\text { Child labour incidence \% } \\
\text { (u.m.) } \\
\end{array}$} & \multicolumn{2}{|c|}{$\%$ of vill. No.(c.m. } \\
\hline & & & & \\
\hline Leather & 0.4 & 17.5 & 2.3 & 7.2 \\
\hline Wood & 4.4 & 19.9 & 22.3 & 7.9 \\
\hline Metal & 0.8 & 18.1 & 4.2 & 9.0 \\
\hline Ceramic & 4.1 & 24.7 & 16.7 & 29.1 \\
\hline Weaving & 1.8 & 18.9 & 9.6 & 26.1 \\
\hline Food & 7.3 & 24.2 & 30.3 & 15.0 \\
\hline Other & 2.8 & 23.0 & 12.0 & 25.3 \\
\hline \multicolumn{5}{|l|}{ By island: } \\
\hline Sumatra & 11.0 & 31.3 & 35.2 & 5.6 \\
\hline Java & 19.5 & 27.3 & 71.5 & 30.2 \\
\hline Bali/Nusa Tenggara & 20.6 & 30.7 & 66.9 & 46.4 \\
\hline Kalimantan & 15.4 & 39.3 & 39.2 & 7.7 \\
\hline Sulawesi & 16.2 & 29.6 & 54.6 & 9.7 \\
\hline Maluku & 7.4 & 23.2 & 31.7 & 4.4 \\
\hline Irian Jaya & 3.2 & 35.1 & 9.1 & 1.6 \\
\hline Total & 15.1 & 29.5 & 51.3 & 17.3 \\
\hline
\end{tabular}


Table 2: Variable definitions and descriptive statistics

\begin{tabular}{|c|c|c|c|c|c|}
\hline Variable & Mean & St. dev. & Min. & Max. & Definition \\
\hline Child labour in small firms* & 0.151 & 0.358 & 0 & 1 & $\begin{array}{l}\text { Indicates child labour being present in } \\
\text { small businesses in the village }\end{array}$ \\
\hline Credit access* & 0.538 & 0.499 & 0 & 1 & $\begin{array}{l}\text { Indicates general access to credit for } \\
\text { households in the village }\end{array}$ \\
\hline Small business credit* & 0.319 & 0.466 & 0 & 1 & $\begin{array}{l}\text { Indicates access to the small business } \\
\text { credit programme (KUK, Kredit Usaha } \\
\text { Kecil) in the village }\end{array}$ \\
\hline $\begin{array}{l}\text { Rotating saving groups } \\
\text { (arisans) }^{*}\end{array}$ & 0.774 & 0.418 & 0 & 1 & $\begin{array}{l}\text { Indicates the presence of traditional } \\
\text { rotating saving and credit groups in the } \\
\text { village }\end{array}$ \\
\hline $\begin{array}{l}\text { Collective labour* } \\
\text { (gotong royong) }\end{array}$ & 0.936 & 0.245 & 0 & 1 & $\begin{array}{l}\text { Indicates the presence of collective labour } \\
\text { arrangements in the village }\end{array}$ \\
\hline Epidemic death rate (\%) & 0.029 & 0.261 & 0 & 28.9 & $\begin{array}{l}\text { Incidence rate of deaths bc. of an } \\
\text { epidemic in previous year (in \%) }\end{array}$ \\
\hline Bad housing & 0.467 & 0.336 & 0 & 1 & $\begin{array}{l}\text { Share of families in the village who live } \\
\text { in a non-permanent building }\end{array}$ \\
\hline Family size & 4.259 & 0.953 & 1.0 & 24.4 & Average family size in the village \\
\hline Unemployment (\%) & 3.948 & 6.051 & 0 & 100 & $\begin{array}{l}\text { Percent share of the unemployed to } \\
\text { village population }\end{array}$ \\
\hline Primary school s* & 0.895 & 0.306 & 0 & 1 & $\begin{array}{l}\text { Indicates the presence of at least one } \\
\text { primary school in the village }\end{array}$ \\
\hline Secondary schools* & 0.314 & 0.464 & 0 & 1 & $\begin{array}{l}\text { Measures the distance to the nearest } \\
\text { secondary school (in } 10 \mathrm{kms} \text { ) }\end{array}$ \\
\hline Families w. electricity & 0.563 & 0.335 & 0 & 1 & Share of families with electricity \\
\hline Village market* & 0.241 & 0.428 & 0 & 1 & $\begin{array}{l}\text { Indicates the presence of a permanent } \\
\text { or semi-permanent market in the village }\end{array}$ \\
\hline Urban* & 0.174 & 0.379 & 0 & 1 & Indicates urban villages \\
\hline Coastal* & 0.130 & 0.336 & 0 & 1 & Indicates villages located on the coast \\
\hline Lower altitudes* & 0.909 & 0.288 & 0 & 1 & $\begin{array}{l}\text { Indicates villages located not higher } \\
\text { than } 800 \mathrm{~m} \text { above sea level }\end{array}$ \\
\hline Distance to market* & 1.218 & 2.184 & 0 & 10 & $\begin{array}{l}\text { Measures the distance to the nearest } \\
\text { permanent market (in } 10 \mathrm{kms} \text { ) }\end{array}$ \\
\hline Population (.000) & 2.99 & 3.81 & 0.01 & 69.8 & Number of village inhabitants (in .000) \\
\hline No. small firms & 17.3 & 63.8 & 0 & 1994 & $\begin{array}{l}\text { Number of small scale manufacturing } \\
\text { firms in the village }\end{array}$ \\
\hline
\end{tabular}


Table 3: Determinants of the number of small firms

\begin{tabular}{lcc}
\hline \multirow{2}{*}{ Dependent } & \multicolumn{2}{c}{ ln no. small firms } \\
Model & \multicolumn{2}{c}{ Tobit } \\
& Coeff. & SE \\
\cline { 2 - 3 } Credit access & $0.771^{* *}$ & $(0.058)$ \\
Small business credit & $0.226^{* *}$ & $(0.058)$ \\
Rotating saving groups (arisans) & $0.208^{*}$ & $(0.095)$ \\
Collective labour (gotong royong) & $0.515^{* *}$ & $(0.143)$ \\
Epidemic death rate (\%) & -0.017 & $(0.073)$ \\
Bad housing & $-0.272^{*}$ & $(0.110)$ \\
Family size & $-0.080^{* *}$ & $(0.027)$ \\
Unemployment (\%) & -0.000 & $(0.004)$ \\
Primary schools & $0.485^{* *}$ & $(0.077)$ \\
Secondary schools & $0.092^{* *}$ & $(0.029)$ \\
Families w. electricity & 0.067 & $(0.119)$ \\
Village market & $0.107^{* *}$ & $(0.036)$ \\
Distance to market & $-0.080^{* *}$ & $(0.017)$ \\
Urban & -0.004 & $(0.074)$ \\
Coastal & $0.185^{*}$ & $(0.080)$ \\
Lower altitudes & $0.445^{* *}$ & $(0.141)$ \\
No.ofobservations & 68305 & \\
R-squared & 0.096 & \\
\hline Notes: Endogenous variable: log of number of small firms +1. \\
The model is estimated by tobit for all villages. The equation \\
includes a constant, province fixed effects and a third order \\
polynomial in population. Robust standard errors (clustered at \\
district level) are reported in parentheses. ${ }^{* * *}, \dagger$ denote \\
significance at the 1, 5, and 10\% level. & \\
\hline
\end{tabular}


Table 4: Child labour in small scale manufacturing (with sample selection)

\begin{tabular}{|c|c|c|c|c|c|c|}
\hline \multirow{4}{*}{$\begin{array}{l}\text { Dep endent } \\
\text { Model }\end{array}$} & \multicolumn{4}{|c|}{ Child labour in small firms } & \multicolumn{2}{|c|}{ Small firm presence } \\
\hline & \multirow{2}{*}{\multicolumn{2}{|c|}{$\begin{array}{l}\text { Conditional probit } \\
\text { (A) Probit }\end{array}$}} & \multicolumn{4}{|c|}{ Probit with sample selection } \\
\hline & & & \multicolumn{2}{|c|}{ (B) Outcome stage } & \multicolumn{2}{|c|}{ (C) Selection stage } \\
\hline & (1) & (2) & (3) & (4) & (5) & (6) \\
\hline Credit access & $\begin{array}{r}-0.003 \\
(0.011)\end{array}$ & $\begin{array}{l}-0.003 \\
(0.015)\end{array}$ & $\begin{array}{l}-0.079^{* *} \\
(0.028)\end{array}$ & $\begin{array}{l}-0.051 \dagger \\
(0.029)\end{array}$ & $\begin{array}{l}0.146^{* *} \\
(0.012)\end{array}$ & $\begin{array}{l}0.137^{* *} \\
(0.012)\end{array}$ \\
\hline $\begin{array}{l}\text { Rotating saving groups } \\
\text { (arisans) }\end{array}$ & $\begin{array}{r}0.014 \\
(0.019)\end{array}$ & $\begin{array}{l}0.038^{*} \\
(0.017)\end{array}$ & $\begin{array}{l}-0.013 \\
(0.022)\end{array}$ & $\begin{array}{l}0.022 \\
(0.022)\end{array}$ & $\begin{array}{l}0.044^{* *} \\
(0.016)\end{array}$ & $\begin{array}{l}0.044^{* *} \\
(0.016)\end{array}$ \\
\hline Collective labour & -0.031 & -0.041 & $-0.073^{*}$ & $-0.076^{*}$ & $0.093^{* *}$ & $0.096^{* *}$ \\
\hline (gotong royong) & $(0.028)$ & $(0.029)$ & $(0.029)$ & $(0.031)$ & $(0.024)$ & $(0.022)$ \\
\hline Epidemic death rate (\%) & $\begin{array}{l}0.099 * * \\
(0.030)\end{array}$ & $\begin{array}{l}0.085^{* *} \\
(0.031)\end{array}$ & $\begin{array}{l}0.091^{* *} \\
(0.032)\end{array}$ & $\begin{array}{l}0.086^{*} \\
(0.034)\end{array}$ & $\begin{array}{l}-0.000 \\
(0.013)\end{array}$ & $\begin{array}{l}0.008 \\
(0.011)\end{array}$ \\
\hline Bad housing & $\begin{array}{r}0.027 \\
(0.020)\end{array}$ & $\begin{array}{l}0.040^{*} \\
(0.018)\end{array}$ & $\begin{array}{l}0.054^{*} \\
(0.021)\end{array}$ & $\begin{array}{l}0.066^{* *} \\
(0.023)\end{array}$ & $\begin{array}{l}-0.061^{* *} \\
(0.020)\end{array}$ & $\begin{array}{l}-0.067^{* *} \\
(0.020)\end{array}$ \\
\hline Family size & $\begin{array}{r}0.004 \\
(0.005)\end{array}$ & $\begin{array}{l}0.001 \\
(0.004)\end{array}$ & $\begin{array}{l}0.011 \dagger \\
(0.006)\end{array}$ & $\begin{array}{l}0.005 \\
(0.005)\end{array}$ & $\begin{array}{l}-0.015^{* *} \\
(0.005)\end{array}$ & $\begin{array}{l}-0.012^{* *} \\
(0.004)\end{array}$ \\
\hline Unemployment (\%) & $\begin{array}{l}0.003^{* *} \\
(0.001)\end{array}$ & $\begin{array}{l}0.003^{* *} \\
(0.001)\end{array}$ & $\begin{array}{l}0.003^{* *} \\
(0.001)\end{array}$ & $\begin{array}{l}0.003^{* *} \\
(0.001)\end{array}$ & $\begin{array}{c}0.000 \\
(0.001)\end{array}$ & $\begin{array}{l}0.001 \\
(0.001)\end{array}$ \\
\hline Primary schools & $\begin{array}{r}0.029 \dagger \\
(0.016)\end{array}$ & $\begin{array}{l}0.027 \dagger \\
(0.014)\end{array}$ & $\begin{array}{l}-0.017 \\
(0.022)\end{array}$ & $\begin{array}{l}0.000 \\
(0.020)\end{array}$ & $\begin{array}{l}0.079^{* *} \\
(0.015)\end{array}$ & $\begin{array}{l}0.071^{* *} \\
(0.011)\end{array}$ \\
\hline Secondary schools & $\begin{array}{r}-0.008 \\
(0.006)\end{array}$ & $\begin{array}{l}-0.006 \\
(0.006)\end{array}$ & $\begin{array}{l}-0.018^{* *} \\
(0.007)\end{array}$ & $\begin{array}{l}-0.014 \dagger \\
(0.007)\end{array}$ & $\begin{array}{l}0.024^{* *} \\
(0.006)\end{array}$ & $\begin{array}{l}0.024^{* *} \\
(0.006)\end{array}$ \\
\hline Families w. electricity & $\begin{array}{r}0.049^{*} \\
(0.023)\end{array}$ & $\begin{array}{l}0.057^{* *} \\
(0.021)\end{array}$ & $\begin{array}{l}0.033 \\
(0.027)\end{array}$ & $\begin{array}{l}0.047 \dagger \\
(0.027)\end{array}$ & $\begin{array}{l}0.026 \\
(0.021)\end{array}$ & $\begin{array}{l}0.040^{*} \\
(0.020)\end{array}$ \\
\hline Village market & $\begin{array}{r}0.011 \\
(0.007)\end{array}$ & $\begin{array}{l}0.009 \\
(0.007)\end{array}$ & $\begin{array}{l}0.003 \\
(0.009)\end{array}$ & $\begin{array}{l}0.007 \\
(0.008)\end{array}$ & $\begin{array}{l}0.020^{* *} \\
(0.008)\end{array}$ & $\begin{array}{l}0.012 \dagger \\
(0.007)\end{array}$ \\
\hline Distance to market & $\begin{array}{r}-0.002 \\
(0.004)\end{array}$ & $\begin{array}{l}-0.000 \\
(0.004)\end{array}$ & $\begin{array}{l}0.007 \\
(0.004)\end{array}$ & $\begin{array}{l}0.006 \\
(0.005)\end{array}$ & $\begin{array}{l}-0.014^{* *} \\
(0.003)\end{array}$ & $\begin{array}{l}-0.015^{* *} \\
(0.003)\end{array}$ \\
\hline Urban & $\begin{array}{r}-0.004 \\
(0.011)\end{array}$ & $\begin{array}{l}-0.002 \\
(0.010)\end{array}$ & $\begin{array}{l}-0.015 \\
(0.013)\end{array}$ & $\begin{array}{l}-0.016 \\
(0.013)\end{array}$ & $\begin{array}{l}0.035^{* *} \\
(0.015)\end{array}$ & $\begin{array}{l}0.062^{* *} \\
(0.013)\end{array}$ \\
\hline Coastal & $\begin{array}{r}-0.008 \\
(0.015)\end{array}$ & $\begin{array}{l}-0.006 \\
(0.015)\end{array}$ & $\begin{array}{l}-0.022 \\
(0.016)\end{array}$ & $\begin{array}{l}-0.013 \\
(0.017)\end{array}$ & $\begin{array}{l}0.031^{*} \\
(0.015)\end{array}$ & $\begin{array}{l}0.019 \\
(0.014)\end{array}$ \\
\hline Lower altitudes & $\begin{array}{r}-0.019 \\
(0.024)\end{array}$ & $\begin{array}{l}-0.023 \\
(0.024)\end{array}$ & $\begin{array}{l}-0.059^{*} \\
(0.025)\end{array}$ & $\begin{array}{l}-0.053 \dagger \\
(0.027)\end{array}$ & $\begin{array}{l}0.088^{* *} \\
(0.025)\end{array}$ & $\begin{array}{l}0.090^{* *} \\
(0.019)\end{array}$ \\
\hline Small business credit & $\begin{array}{r}0.021 \dagger \\
(0.011)\end{array}$ & $\begin{array}{l}0.021 \dagger \\
(0.011)\end{array}$ & & & $\begin{array}{l}0.058^{* *} \\
(0.013)\end{array}$ & $\begin{array}{l}0.054^{* *} \\
(0.012)\end{array}$ \\
\hline Rho & & & $\begin{array}{l}-0.663^{*} \\
(0.377)\end{array}$ & $\begin{array}{c}-0.571^{*} \\
(0.198)\end{array}$ & & \\
\hline Further controls & Yes & Yes & Yes & Yes & Yes & Yes \\
\hline Fixed effects & Prov. & Dist. & Prov. & Dist. & Prov. & Dist. \\
\hline No. of provinces & 30 & 30 & 30 & 30 & 30 & 30 \\
\hline No. of districts & 372 & 365 & 372 & 360 & 372 & 360 \\
\hline $\mathrm{N}$ (observations) & 35073 & 35001 & 35073 & 34847 & 68305 & 67667 \\
\hline Pseudo R2 & 0.035 & 0.091 & & & & \\
\hline
\end{tabular}

Notes: The table reports marginal effects (evaluated at the sample mean) from probit regressions conditional on the presence of small firms in a village, and from a probit model with sample selection correction. All equations include a constant and province or district fixed effects. Further controls include a third order polynomial in population size at the selection stage and a bivariate third order polynomial in population size, the number of small firms, and all their interactions in child labour regressions. Robust standard errors (clustered at district level) are reported in parentheses. ${ }^{* * *},+$ denote significance at the 1,5 , and $10 \%$ level. 
Figure 1: Regional incidence and intensity of child work (province level)
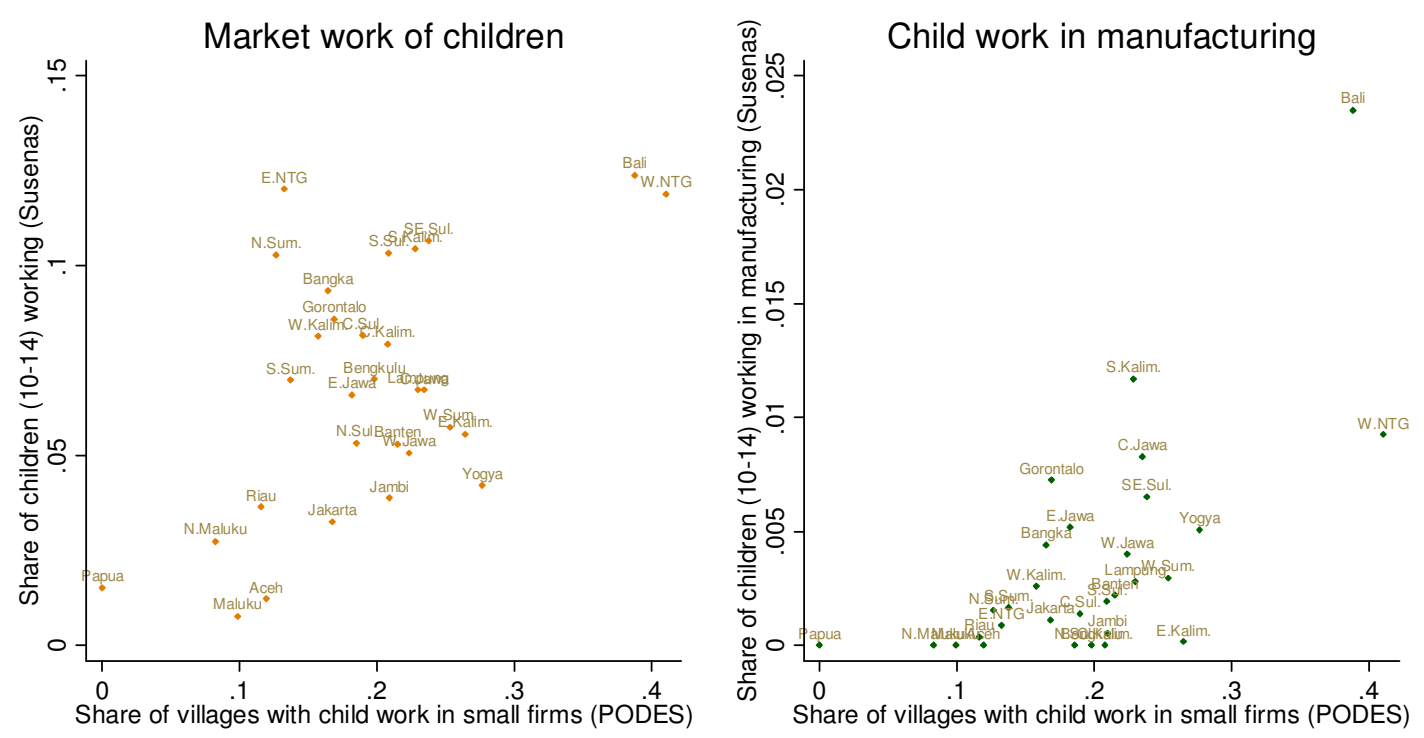
Table A1: Child labour incidence in small scale industries by island (Part 1)

\begin{tabular}{|c|c|c|c|c|}
\hline \multirow{2}{*}{$\begin{array}{l}\text { Isle (No. of villages) } \\
\text { By industry }\end{array}$} & \multicolumn{2}{|c|}{ Child labour incidence $\%$} & \multicolumn{2}{|c|}{ Small firms } \\
\hline & (u.m.) & (c.m.) & $\%$ of vill. & No.(c.m.) \\
\hline Sumatera (21113) & 11.0 & 31.3 & 35.2 & 5.6 \\
\hline Leather & 0.2 & 17.9 & 1.0 & 4.0 \\
\hline Wood & 3.2 & 25.2 & 12.6 & 3.9 \\
\hline Metal & 0.5 & 21.0 & 2.5 & 4.2 \\
\hline Ceramic & 2.2 & 23.2 & 9.6 & 14.0 \\
\hline Weaving & 1.3 & 19.7 & 6.7 & 10.8 \\
\hline Food & 5.7 & 27.4 & 20.7 & 8.7 \\
\hline Other & 2.1 & 27.4 & 7.5 & 14.2 \\
\hline Jawa (24952) & 19.5 & 27.3 & 71.5 & 30.2 \\
\hline Leather & 0.8 & 18.3 & 4.5 & 8.3 \\
\hline Wood & 5.1 & 15.4 & 33.0 & 8.4 \\
\hline Metal & 0.9 & 15.9 & 5.7 & 11.0 \\
\hline Ceramic & 5.6 & 21.9 & 25.4 & 37.9 \\
\hline Weaving & 1.7 & 17.6 & 9.8 & 19.1 \\
\hline Food & 10.6 & 21.9 & 48.4 & 18.4 \\
\hline Other & 3.6 & 19.1 & 18.9 & 32.0 \\
\hline Bali/Nusa Tengg. (3974) & 20.6 & 30.7 & 66.9 & 46.4 \\
\hline Leather & 0.2 & 11.7 & 1.9 & 2.7 \\
\hline Wood & 7.4 & 30.6 & 24.3 & 23.7 \\
\hline Metal & 1.3 & 19.6 & 6.8 & 18.2 \\
\hline Ceramic & 5.4 & 29.5 & 18.1 & 44.3 \\
\hline Weaving & 7.2 & 18.1 & 39.7 & 53.4 \\
\hline Food & 6.6 & 27.4 & 24.3 & 19.9 \\
\hline Other & 3.7 & 25.7 & 14.3 & 37.0 \\
\hline Kalimantan (6014) & 15.4 & 39.3 & 39.2 & 7.7 \\
\hline Leather & 0.1 & 12.9 & 0.5 & 2.7 \\
\hline Wood & 3.8 & 31.7 & 12.0 & 6.7 \\
\hline Metal & 0.9 & 23.5 & 3.7 & 4.9 \\
\hline Ceramic & 7.1 & 44.4 & 16.0 & 21.8 \\
\hline Weaving & 1.3 & 35.3 & 3.7 & 17.4 \\
\hline Food & 5.6 & 26.5 & 21.0 & 8.6 \\
\hline Other & 2.9 & 35.5 & 8.0 & 8.9 \\
\hline
\end{tabular}

Notes: Provinces are as of 2002. The unconditional mean (u.m.) of child labour gives the average prevalence rate of child labour over all villages. Conditional means (c.m.) are calculated for the subsample of those villages where small firms operate in the given industry. 
Table A1: Child labour incidence in small scale industries by island (Part 2)

\begin{tabular}{lcccc}
\hline \multirow{2}{*}{ Isle (No. of villages) } & \multicolumn{2}{c}{ Child labour incidence $\%$} & \multicolumn{2}{c}{ Small firms } \\
By industry & (u.m.) & (c.m.) & \% of vill. & No.(c.m.) \\
\cline { 2 - 5 } Sulawesi (7659) & 16.2 & 29.6 & 54.6 & 9.7 \\
Leather & 0.1 & 19.2 & 0.7 & 3.2 \\
Wood & 6.7 & 20.6 & 32.3 & 4.5 \\
Metal & 0.8 & 16.0 & 4.9 & 5.1 \\
Ceramic & 3.4 & 22.7 & 15.2 & 10.0 \\
Weaving & 1.9 & 18.0 & 10.7 & 25.2 \\
Food & 6.5 & 27.1 & 23.9 & 10.1 \\
Other & 2.8 & 27.0 & 10.5 & 13.0 \\
Maluku (1577) & 7.4 & 23.2 & 31.7 & 4.4 \\
Leather & 0.3 & 23.5 & 1.1 & 2.1 \\
Wood & 2.6 & 35.3 & 7.4 & 3.9 \\
Metal & 0.6 & 35.7 & 1.8 & 2.1 \\
Ceramic & 2.8 & 20.0 & 14.0 & 8.5 \\
Weaving & 1.3 & 17.7 & 7.2 & 13.6 \\
Food & 3.7 & 28.4 & 12.9 & 12.2 \\
Other & 1.0 & 20.0 & 4.8 & 6.1 \\
& & & & \\
Irian Jaya (3507) & 3.2 & 35.1 & 9.1 & 1.6 \\
Leather & 0.1 & 7.5 & 1.5 & 11.3 \\
Wood & 1.2 & 28.6 & 4.2 & 15.5 \\
Metal & 0.2 & 31.8 & 0.6 & 2.3 \\
Ceramic & 0.9 & 40.0 & 2.3 & 5.7 \\
Weaving & 0.2 & 37.5 & 0.5 & 1.9 \\
Food & 1.4 & 44.1 & 3.2 & 19.3 \\
Other & 0.5 & 50.0 & 0.9 & 6.8 \\
\hline Notes: Provinyyyy & & & & \\
\hline
\end{tabular}

Notes: Provinces are as of 2002. The unconditional mean (u.m.) of child labour gives the average prevalence rate of child labour over all villages. Conditional means (c.m.) are calculated for the subsample of those villages where small firms operate in the given industry. 
Table A2: Average number of firms in a village by specialization patterns in child labour

Average No. of firms

No. obs. in given sector

Villages with child labour

in neither sector

in food but not in wood sector

in wood but not in food sector

in both sectors

Villages with child labour

in neither sector

in food but not in ceramic sector

in ceramic but not in food sector

in both sectors

Villages with child labour

in neither sector

in wood but not in ceramic sector

in ceramic but not in wood sector

in both sectors

Villages with child labour

in neither sector

in food but not in other sectors

in other but not in food sector

in both sectors

Villages with child labour

in neither sector

in wood but not in other sectors

in other but not in wood sector

in both sectors

Villages with child labour

in neither sector

in ceramic but not in other sectors

in other but not in ceramic sector

in both sectors

Food

382 (A) 15.7

1229 (C) 25.3

434 (E) 16.7

1100 (G) 15.0

Food

170

686

490

977

(A) 20.4

(C) 30.2

(E) 15.3

(G) 21.3

Wood

(B) 6.1

(H) $\quad 10.3$

\section{Wood Ceramic}

\section{Ceramic Others}

Means test

(D) 6.6

(F) 24.8

$\mathrm{H}$-alt. p-value

$\mathrm{A}<\mathrm{C} \quad 0.0001$

$\mathrm{B}<\mathrm{F} \quad 0.0001$

$\mathrm{E}<\mathrm{G} \quad 0.6898$

$\mathrm{D}<\mathrm{H} \quad 0.0090$

$\begin{array}{llrllll}492 & \text { (A) } & 8.4 & \text { (B) } & 12.0 & \text { A }<\text { C } & 0.0003 \\ 178 & \text { (C) } & 39.2 & \text { (D) } & 16.6 & \text { B }<\text { F } & 0.0000 \\ 416 & \text { (E) } & 5.5 & \text { (F) } & 77.8 & \text { E }<\text { G } & 0.0085 \\ 677 & \text { (G) } & 10.4 & \text { (H) } & 25.0 & \text { D }<\text { H } & 0.0356\end{array}$

\begin{tabular}{|c|c|c|c|c|c|c|}
\hline \multicolumn{3}{|c|}{ Food } & \multicolumn{2}{|c|}{ Others } & \multirow[b]{2}{*}{$\mathrm{A}<\mathrm{C}$} & \multirow[b]{2}{*}{0.4074} \\
\hline 218 & (A) & 21.2 & (B) & 20.3 & & \\
\hline 0 & (C) & 22.5 & (D) & 14.9 & $\mathrm{~B}<\mathrm{F}$ & 0.0000 \\
\hline 52 & (E) & 10.8 & $(F)$ & 62.5 & $\mathrm{E}<\mathrm{G}$ & 0.0000 \\
\hline 90 & (G) & 17.8 & $(\mathrm{H})$ & 29.3 & $\mathrm{D}<\mathrm{H}$ & 0.0000 \\
\hline
\end{tabular}

\begin{tabular}{|c|c|c|c|c|c|c|}
\hline & \multicolumn{2}{|c|}{ Wood } & \multicolumn{2}{|c|}{ Others } & & \\
\hline 510 & (A) & 7.2 & (B) & 19.4 & $\mathrm{~A}<\mathrm{C}$ & 0.0001 \\
\hline 297 & (C) & 33.8 & (D) & 14.2 & $\mathrm{~B}<\mathrm{F}$ & 0.0000 \\
\hline 578 & (E) & 6.5 & (F) & 56.2 & $E<G$ & 0.0170 \\
\hline 802 & (G) & 9.5 & $(\mathrm{H})$ & 31.0 & $\mathrm{D}<\mathrm{H}$ & 0.0000 \\
\hline
\end{tabular}

$\begin{array}{lllllll}239 & \text { (A) } & 12.7 & \text { (B) } & 21.0 & \text { A < C } & 0.0000 \\ 325 & \text { (C) } & 73.8 & \text { (D) } & 19.0 & \text { B < F } & 0.0002 \\ 287 & \text { (E) } & 14.0 & \text { (F) } & 48.4 & \text { E < G } & 0.0000 \\ 547 & \text { (G) } & 34.5 & \text { (H) } & 37.1 & \text { D < H } & 0.0002\end{array}$

Notes: All observations refer to villages where children work in at least one industry. Other sectors include small scale manufacturing of metals, textiles, leather and other small manufacturers. Reported p-values refer to pairwise one-sided t-tests of equality of the average number of firms with and without the presence of child labour in a given sector. 
Table A2 relates the specialization patterns of child labour across industries to the average number of firms in those industries. As location factors may be industryspecific, we only look at villages where two industries from any industry-pair are located, and compare the average number of firms in a given industry with and without child labour occurrence, given child labour outcomes in the other industry. In 22 (19) out of 24 comparisons, the average number of firms is significantly larger in villages where child labour occurs in that industry compared to villages without child labour in that industry at the $10 \%(1 \%)$ significance level. For instance if we compare the villages that have child labour in the food, but not in the ceramic sector with those villages that have child labour in both sectors, then the number of ceramic firms in the former group are significantly smaller than in the latter. Likewise if we compare the former group of villages with a group that has both types of firm, but no child labour in either sector, then the number of food processing firms is significantly higher in the former than in the latter group. This indicates the importance of the number of firms for child labour incidence even if we control for industry specific location characteristics. 
Table A3: Determinants of the number of small firms, correcting for the location decision

\begin{tabular}{|c|c|c|c|c|}
\hline \multirow{2}{*}{$\begin{array}{l}\text { Model } \\
\text { Stage }\end{array}$} & \multicolumn{2}{|c|}{ (1) } & \multicolumn{2}{|c|}{$(2)$} \\
\hline & Outcome & Selection & Outcome & Selection \\
\hline \multirow[t]{2}{*}{ Dependent } & $\begin{array}{l}\text { ln No. Small } \\
\text { firms }\end{array}$ & $\begin{array}{l}\text { Small firm } \\
\text { presence }\end{array}$ & $\begin{array}{l}\text { In No. Small } \\
\text { firms }\end{array}$ & $\begin{array}{c}\text { Small firm } \\
\text { presence }\end{array}$ \\
\hline & $\begin{array}{l}0.609 * * \\
(0.059)\end{array}$ & $\begin{array}{l}0.139 * * \\
(0.011)\end{array}$ & $\begin{array}{l}0.615^{* *} \\
(0.059)\end{array}$ & $\begin{array}{l}0.140^{* *} \\
(0.011)\end{array}$ \\
\hline \multirow[t]{2}{*}{ Small business credit } & $0.210^{* *}$ & $0.052^{* *}$ & $0.210^{* *}$ & $0.052^{* *}$ \\
\hline & $(0.051)$ & $(0.012)$ & $(0.051)$ & $(0.012)$ \\
\hline \multirow[t]{2}{*}{ Savinggroups (arisan) } & 0.093 & $0.043^{* *}$ & & $0.030^{* *}$ \\
\hline & $(0.095)$ & $(0.016)$ & & $(0.008)$ \\
\hline \multirow[t]{2}{*}{ Collective labour (gotong royong) } & $0.428^{* *}$ & $0.086^{* *}$ & $0.458^{* *}$ & $0.090^{* *}$ \\
\hline & $(0.137)$ & $(0.023)$ & $(0.133)$ & $(0.022)$ \\
\hline \multirow[t]{2}{*}{ Epidemic death rate (\%) } & -0.037 & 0.001 & -0.036 & 0.001 \\
\hline & $(0.078)$ & $(0.013)$ & $(0.078)$ & $(0.013)$ \\
\hline \multirow[t]{2}{*}{ Bad housing } & $-0.191 \dagger$ & $-0.055^{* *}$ & $-0.192 \dagger$ & $-0.056^{* *}$ \\
\hline & $(0.103)$ & $(0.019)$ & $(0.103)$ & $(0.019)$ \\
\hline \multirow[t]{2}{*}{ Family size } & $-0.070^{* *}$ & $-0.013^{* *}$ & $-0.070 * *$ & $-0.014^{* *}$ \\
\hline & $(0.025)$ & $(0.005)$ & $(0.025)$ & $(0.005)$ \\
\hline \multirow[t]{2}{*}{ Unemployment (\%) } & -0.000 & -0.000 & -0.000 & -0.000 \\
\hline & $(0.004)$ & $(0.001)$ & $(0.004)$ & $(0.001)$ \\
\hline \multirow[t]{2}{*}{ Primary schools } & $0.411^{* *}$ & $0.081^{* *}$ & $0.419 * *$ & $0.083^{* *}$ \\
\hline & $(0.065)$ & $(0.014)$ & $(0.066)$ & $(0.014)$ \\
\hline \multirow[t]{2}{*}{ Secondary schools } & $0.059 *$ & $0.021^{* *}$ & $0.060^{*}$ & $0.021^{* *}$ \\
\hline & $(0.026)$ & $(0.006)$ & $(0.026)$ & $(0.006)$ \\
\hline \multirow[t]{2}{*}{ Families w. electricity } & -0.012 & 0.018 & -0.000 & 0.019 \\
\hline & $(0.114)$ & $(0.021)$ & $(0.112)$ & $(0.021)$ \\
\hline \multirow[t]{2}{*}{ Village market } & $0.116^{* *}$ & $0.016^{*}$ & $0.116^{* *}$ & $0.016^{*}$ \\
\hline & $(0.032)$ & $(0.007)$ & $(0.032)$ & $(0.007)$ \\
\hline \multirow[t]{2}{*}{ Distance to market } & $-0.048^{* *}$ & $-0.016^{* *}$ & $-0.049 * *$ & $-0.016^{* *}$ \\
\hline & $(0.016)$ & $(0.003)$ & $(0.016)$ & $(0.003)$ \\
\hline \multirow[t]{2}{*}{ Urban } & -0.056 & 0.017 & -0.055 & 0.017 \\
\hline & $(0.069)$ & $(0.014)$ & $(0.069)$ & $(0.014)$ \\
\hline \multirow[t]{2}{*}{ Coastal } & $0.156^{*}$ & $0.031^{*}$ & $0.158^{*}$ & $0.032^{*}$ \\
\hline & $(0.077)$ & $(0.014)$ & $(0.077)$ & $(0.014)$ \\
\hline \multirow[t]{2}{*}{ Lower altitudes } & $0.345^{* *}$ & $-0.081^{* *}$ & $0.349 * *$ & $-0.081^{* *}$ \\
\hline & $(0.130)$ & $(0.024)$ & $(0.130)$ & $(0.024)$ \\
\hline \multirow[t]{2}{*}{ Mill's lambda } & $1.781^{* *}$ & & $1.778^{* *}$ & \\
\hline & $(0.046)$ & & $(0.046)$ & \\
\hline
\end{tabular}

Notes: The two models in Table A3 are estimated by a two-step Heckman procedure where the dummy for firms being present is the dependent variable at the selection stage and the number of small firms is the dependent variable at the outcome stage. Model 1 presents the results identified only by the nonlinear functional form (without exclusion restrictions), model 2 uses the presence of saving groups as exclusion restriction to identify the first stage. This variable is only correlated 
with the presence, but not with the numbers of firms at the second stage. As this does not constitute a formal test of the exclusion restriction, we present these results only as informative evidence, to corroborate our findings from the tobit regressions presented in Table 3.

Estimations are based on 68305 observations, 35073 of which are uncensored. Both models include a constant, province fixed effects, and a third order polynomial in population. Robust standard errors (clustered at district level) are reported in parentheses. The selection stage presents marginal effects evaluated at the at the sample mean. ${ }^{* * *},+\dagger$ denote significance at the 1,5 , and $10 \%$ level. 